\title{
HIGH-SPEED BRAIN-COMPUTER COMMUNICATION INTERFACE BASED ON CODE-MODULATED VISUAL EVOKED POTENTIALS
}

\author{
Grigoryan $\mathrm{RK}^{1} \otimes$, Filatov $\mathrm{DB}^{1,2}$, Kaplan $\mathrm{AY}^{1}$
}

${ }^{1}$ Faculty of Biology, Lomonosov Moscow State University, Moscow, Russia

2 Department of Mechanics and Mathematics, Lomonosov Moscow State University, Moscow, Russia Brain-computer interface (BCl) technologies are actively used in clinical practice to communicate with patients unable to speak and move. Such interfaces imply
identifying potentials evoked by stimuli meaningful to the patient in his/her EEG and interpreting these potentials into inputs for the communication software. The
stimuli can take form of highlighted letters on a screen, etc. This study aimed to investigate EEG indicators and assess the command input performance of a
promising type of $\mathrm{BCl}$ utilizing the so-called code-modulated visual evoked potentials (CVEP) appearing in response to a certain sequence of highlights of the desired
letter. The operation of the interface was studied on 15 healthy volunteers. During the experiments, we changed the speed of stimuli demonstration and inverted the
order of flashing. It was established that the optimal speed of stimulation significantly depends on individual traits of the person receiving the stimuli, and inversion
of their sequence does not affect operation of the interface. The median accuracy of selection of commands was as follows: $1 \mathrm{~s}$ stimulation cycle mode - -0.96
and 0.95 (information transfer rate 142 and 141 bit per minute); $2 \mathrm{~s}$ stimulation cycle mode $-1 ; 0.5 \mathrm{~s}$ cycle -0.33 . The evoked potentials were most expressed
at the Oz site. It was assumed that CVEP-based brain-computer interfaces can be optimized through individualization of the set of stimulation parameters. Keywords: neurocomputer interfaces, evoked potentials, EEG, Electroencephalogram, BCl, brain-computer interfaces, speech disorders, CVEP, code-modulated visual evoked potentials

Author contribution: Grigoryan RK — experiment planning and conducting, data processing, article authoring; Filatov DB - experiment planning, software development, article authoring; Kaplan AY — task setting, experiment planning, general research effort management, article authoring.

Compliance with ethical standards: the study was approved by the ethical commission of the Lomonosov Moscow State University's Faculty of Biology (Protocol № 29-ch of December 11 2015); the participants signed a voluntary informed consent.

$\triangle$ Correspondence should be addressed: Rafael K. Grigoryan

Leninskie Gory 1, bld. 12, Moscow, 119234; grraph.bio@gmail.com

Received: 29.07.2018 Accepted: 24.03.2019 Published online: 04.04.2019

DOI: $10.24075 /$ brsmu.2019.019

\section{ВЫСОКОСКОРОСТНОЙ КОММУНИКАЦИОННЫЙ ИНТЕРФЕЙС МОЗГ-КОМПЬЮТЕР НА ОСНОВЕ КОДИРОВАННЫХ ЗРИТЕЛЬНЫХ ВЫЗВАННЫХ ПОТЕНЦИАЛОВ}

Р. К. Григорян ${ }^{1}$, Д. Б. Филатов ${ }^{1,2}$, А. Я. Каплан

${ }^{1}$ Биологический факультет, Московский государственный университет имени М. В. Ломоносова, Москва, Россия

2 Механико-математический факультет, Московский государственный университет имени М. В. Ломоносова, Москва, Россия

\begin{abstract}
Технологии интерфейсов мозг-компьютер (ИМК) активно используют в клинической практике для обеспечения коммуникации с пациентами, не способными к речи и движениям. Ввод команд в компьютер посредством таких интерфейсов осуществляют на основе выделения в ЭЭГ вызванных потенциалов в ответ на значимые для пользователя стимулы, например подсвеченные на экране буквы. Целью работы было исследовать показатели ЭЭГ и эффективность ввода команд в перспективном типе ИМК на основе так называемых кодированных вызванных потенциалов, возникающих в ответ на определенную последовательность подсветок нужной буквы. На 15 здоровых добровольцах изучали работу такого интерфейса на разных скоростях подачи стимульных последовательностей при их инвертировании, когда подсветку и ее отсутствие меняли местами. Показано, что оптимальное значение скорости стимуляции имеет значительную индивидуальную вариабельность, а инверсия стимульной последовательности не оказывает влияния на работу интерфейса. Медианная точность выбора команд составила: в режимах с циклом стимуляции 1 с — 0,96 и 0,95 (скорость передачи информации 142 и 141 бит/мин); в режиме со стимульным циклом 2 с - 1; с циклом 0,5 с - 0,33. Максимальную выраженность вызванных потенциалов наблюдали в отведении Oz. Сделано предположение о том, что оптимизация нейроинтерфейсов на основе кодированных вызванных потенциалов возможна на основе индивидуального подбора параметров стимуляции.
\end{abstract}

Ключевые слова: нейроинтерфейсы, вызванные потенциалы, ЭЭГ, электроэнцефалограмма, ИМК, интерфейс мозг-компьютер, нарушения речи, КЗВП, кодированные зрительные вызванные потенциалы

Информация о вкладе авторов: Р. К. Григорян - планирование и проведение эксперимента, обработка данных, подготовка статьи; Д. Б. Филатов планирование эксперимента, разработка программного обеспечения (ПО), подготовка статьи; А. Я. Каплан - постановка задачи, планирование эксперимента, руководство проведением исследования, подготовка статьи.

Соблюдение этических стандартов: исследование одобрено этической комиссией Биологического факультета МГУ имени М. В. Ломоносова (протокол № 29-ч от 11 декабря 2015 г.); испытуемые подписали добровольное информированное согласие на участие в исследовании.

$\triangle$ Для корреспонденции: Рафаэль Каренович Григорян

ул. Ленинские горы, д. 1, стр. 12, г. Москва, 119234; grraph.bio@gmail.com

Статья получена: 29.07.2018 Статья принята к печати: 24.03.2019 Опубликована онлайн: 04.04.2019

DOI: $10.24075 /$ vrgmu.2019.019

Brain-computer interface $(\mathrm{BCl})$ is a technology that allows patients with speech and movement disorders to control a computer through the analysis of correlates of their neuronal activity. $\mathrm{BCl}$ requires the user to focus attention either on internal images, e.g., limb movements, or on objects on the screen, like letters needed at the given moment. BCl systems translate such mental efforts into computer input commands by registering specific EEG markers peculiar to such efforts [1-3]. Interfaces that make use of visual potentials evoked, for example, by flashing objects on the screen, offer a wide range 
of EEG-detectable commands, their amount being the same as that of on-screen stimuli. P300 component is the traditional EEG marker signaling of the user's attention to a specific event, like flashing a certain letter [4, 5]. Such interfaces have lately been actively introduced into the medical rehabilitation practice to enable communication with patients suffering from severe speech and movement disorders [6]. Their reliability in translating commands given by cognitively intact patients is sufficient, but the speed of operation is quite low, which is a drawback. For example, a comparison of $\mathrm{BCl}$ capabilities as used by healthy people and patients with amyotrophic lateral sclerosis has revealed that the text typing rate does not exceed 2-3 letters per minute with each target object shown 14 times. With the accuracy in both groups exceeding 95\%, such a rate translates to 11-14 bits per minute (bpm) [7], which makes $\mathrm{BCl}$ using P300 as marker uncomfortable even for healthy people. Code-modulated visual evoked potentials (CVEP) promise to speed up $\mathrm{BCl}$ transfer rates. CVEP is a joint EEG-detectable response to the special irregular frequency sequences of flashes of the required on-screen object. Such sequences stimulate a steady state visually evoked potential (SSVEP) registered by EEG, which is phase-locked with stimulation. Phase synchronization, which is also peculiar to SSVEPenabled $\mathrm{BCl}$ featuring regular frequency stimulation, allows the evoked potential to retain the properties of the stimuli sequence to a certain degree, in particular - its cyclicity, autocorrelation and spectral characteristics. Presenting a number of visual stimuli through a number of different sequences that correlate with each other at least minimally allows distinguishing between the evoked potentials brought by different stimuli through a correlation analysis. There are various sets of binary sequences with suitable cross-correlation properties, such as the Gold codes, Barker codes and m-sequences. They are used to identify signals carried on the same frequency in various spheres, like mobile communications and satellite navigation.

$\mathrm{M}$-sequence is a pseudo-random binary sequence that has a single peak of autocorrelation function at zero shift. With a cyclic shift, one m-sequence can produce several sequences not correlated with each other, which facilitates its application in $\mathrm{BCl}$ featuring a large number of stimuli, as it shortening the classifier learning period. To distinguish between the potentials evoked by different stimuli, it is necessary to assemble a learning sample. Such a sample should contain potentials corresponding to each stimulus. With each stimulus using its own binary sequence generated by a single $\mathrm{m}$-sequence, it is enough to get the reference evoked potential peculiar only to that binary sequence. Then, it is possible to detect the target stimulus by shift of the correlation function's peak between spatially filtered sections of the recorded EEG and that reference evoked potential. As a result, the duration of learning does not depend on the number of different stimuli, which allows using the amount of stimuli sufficient to print a text.

Canonical correlation analysis of EEG allows reliable detection of short instances of code-modulated evoked potentials synchronous with the flashes of the currently needed on-screen object. The number of stimuli activation repetition cycles therein can be as low as 2 or 3 . Thus enabled $\mathrm{BCl}$ offer information transfer rates in excess of $100 \mathrm{bpm}$ [8]. Both EEG and electrocorticogram [9] allow registering code-modulated evoked potentials; they can be used to optimize $\mathrm{BCl}$ operation to adjust to error-related potentials and to utilize color gamut in the stimulus environment [11].

Seeking to find the optimal modes of code-modulated on-screen object flashing for $\mathrm{BCl}$, we tested operation with different sequences and rates of stimuli flashes.

\section{METHODS}

\section{Participants}

Fifteen healthy volunteers ( 7 female and 8 male) aged 18-30 years participated in the study. The inclusion criteria were: no history of neurological diseases, including epilepsy; normal or corrected vision. The exclusion criteria were: age different from the required; history of neurological diseases; vision problems.

\section{EEG registration}

We used the Neurovisor-BMM 40 EEG amplifier (Meditsinskiye Computerniye Systemy; Russia) to record biopotentials, and 22 channels (FCz, C3, C1, Cz, C2, C4, CP3, CP1, CPz, CP2, CP4, P5, P3, Pz, P4, P6, PO3, POz, PO4, O1, Oz, O2) with $\mathrm{AFz}$ as a grounding electrode and two averaged ear electrodes as reference. Before recording, we checked the interelectrode impendance; the recording was started after the resistance was brought to the values below $10 \mathrm{kOhm}$. The sampling rate was $500 \mathrm{~Hz}$.

\section{Experimental rig}

The experiment was controlled from a computer using custom software developed by the authors in $\mathrm{C}++$. The stimuli were shown to participants on a 24-inch display with a refresh rate of $120 \mathrm{~Hz}$. The participants sat in a chair approximately 60 $\mathrm{cm}$ away from the display. A photosensor was used to ensure synchronization of EEG recording and stimuli presentation.

\section{Stimuli presentation}

The objects were presented in 32 square cells ( 4 by 8 table) containing letters on a black background. The stimulation was effected through changing the color of the cell from black to white.

The color change algorithm was determined by a 63-bit $\mathrm{m}$-sequence. Each cell changed color in accordance with its own m-sequence derived from the basis sequence through 2-bit cyclic shifts. Thus, activation of the first cell followed the basis sequence, that of the second cell was shifted by 2 bits, of the 10th - by 18 bits, etc. Overall, we used two basis m-sequences: basis - $[0,0,0,0,0,1,1,1,1,1,0,1,1,1,1,0,0,1,1$, $1,0,1,0,1,1,0,0,0,0,1,0,1,1,1,0,0,0,1,1,0,1,1,0,1,0,0,1,0,0$, $0,1,0,0,1,1,0,0,1,0,1,0,1,0]$ and inverted $-[1,1,1,1,1,0,0,0$, $0,0,1,0,0,0,0,1,1,0,0,0,1,0,1,0,0,1,1,1,1,0,1,0,0,0,1,1,1,0$, $0,1,0,0,1,0,1,1,0,1,1,1,0,1,1,0,0,1,1,0,1,0,1,0,1]$.

There are no other 63-bit m-sequences that are not cyclic shifts of these. The inverted sequence is similar to the basis one in terms of autocorrelation properties, but it generates a significantly different visual stimulation.

In the course of our experiment, we tested four modes of $\mathrm{BCl}$, each with its own $\mathrm{m}$-sequence and stimulation rate. The first two modes featured basis and inverted sequences, respectively. The period was 1 second. Parameters of the third, "slow" mode - basis sequence and 2-second period, those of the fourth, "fast" mode — period of $500 \mathrm{~ms}$.

Thus, the duration of one bit in white and black colors in standard, fast and slow modes were approximately 16, 8 and $32 \mathrm{~ms}$, respectively.

\section{Structure of the study}

Each volunteer participated in 4 experimental sessions. The order of modes was selected at random after briefing and electrodes 
placement. Each mode session began with the classifier learning from the participant's viewing one of the stimuli for 40 full sequence presentation periods. After that, the participant had to enter 32 commands following a predetermined order of concentration on stimuli. Entering a command took a carefu look at a particular letter while concentrating on its flashes. After a few seconds, the system produces an answer, which could be correct or wrong. Then the stimulation is stopped. Following a break of several seconds, the stimulation resumed and the participant had to try to enter another command.

The command was considered entered when the classifier reached a certain threshold. The accuracy of the choice of commands was determined as the ratio of correctly entered commands to the total number of input attempts.

\section{Pattern classification}

Canonical correlation analysis allows obtaining the weights of channels used to spatially filter EEG and to isolate a significant response to the sequence of stimuli. Weights obtained through analyzing EEG readings recorded while learning were used to decrease the signal's dimension. Learning yielded a singlechannel m-sequence response signal averaged over 40 full periods. During actual operation, a one-dimensional signal peculiar to demonstration of the $\mathrm{m}$-sequence in full triggers compilation of the function describing its correlation with the signal obtained during learning. The command selected by the user is determined by the shift of peak of this correlation function. Determining the number of the target stimulus takes division of the correlation function's time shift maximum by the time of one bit implementation and the shift between successive stimuli.

\section{Data analysis}

We used the scipy 1.1.0 package [12] to process the results, normalized cross-correlation to build correlation maps and applied the Wilcoxon test (Holm-Sidak multiple comparison correction) to pairwise comparisons.
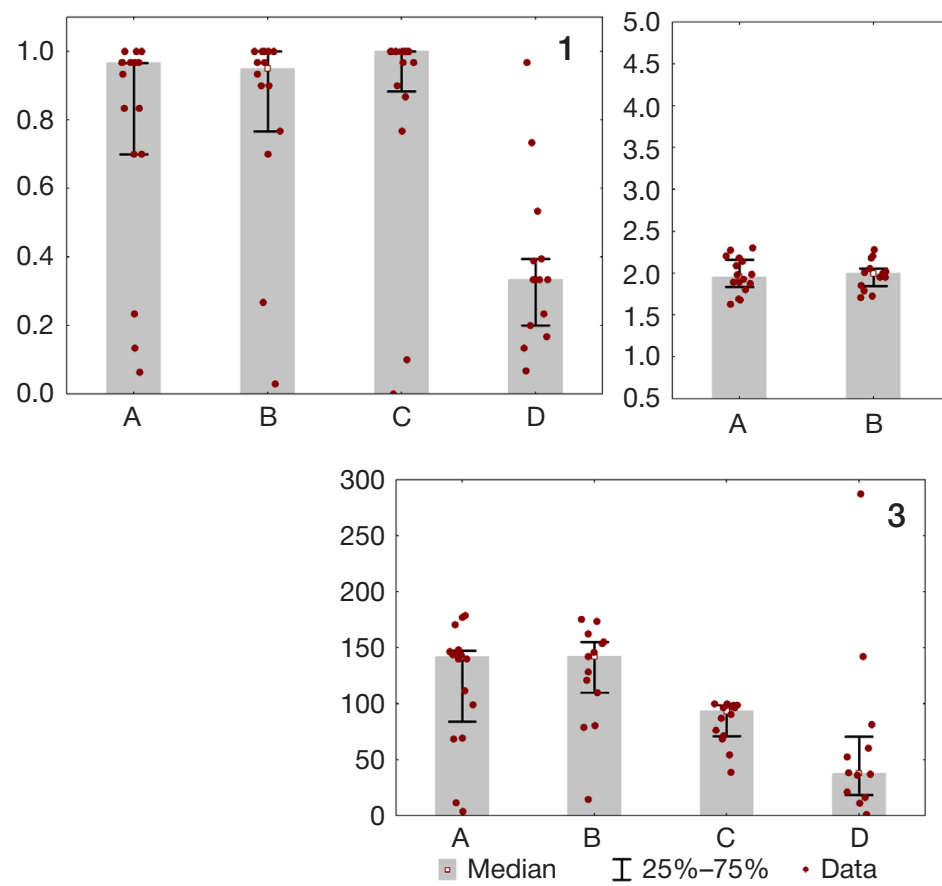

Fig. 1. Neurointerface utilization by users: indicators. 1 - command input accuracy; 2 - average command input time (in seconds); 3 - information transfer rate, bpm; A — basis stimulus sequence; B — inverted; C — slow mode; D — fast mode

\section{RESULTS}

\section{Assessment of classification accuracy and information transfer rate}

In slow mode, with the m-sequence period of $2 \mathrm{~s}$, the median accuracy of command selection reached 1 (Fig. 1). In basis and inverted m-sequence modes the accuracy was 0.96 and 0.95 , respectively. In the fast mode the median accuracy was 0.33, which makes it the only mode the accuracy of which is significantly different from that of all other modes with the multiple comparison correction applied $(p<0.05)$. However, one participant showed the accuracy of 0.96 in this mode, a result that cannot be explained by random reasons since it was preceded by input of 32 commands.

The command input rate is another important property of $\mathrm{BCl}$. In the modes with $\mathrm{m}$-sequence period of $1 \mathrm{~s}$, the median time required to identify one command was $2 \mathrm{~s}$. In the slow mode, the figure was $3.5 \mathrm{~s}$, in the fast mode $-1.2 \mathrm{~s}$.

Information transfer rate is an integrative indicator of the $\mathrm{BCl}$ quality: it combines both the rate and the accuracy of command selection. We used the Shannon definition as applied to neurocomputer interfaces [13] to calculate the indicator. The median information transfer rate in the basis and inverted sequence modes was 141 and $142 \mathrm{bpm}$, in the slow mode $93 \mathrm{bpm}$, while the fast mode yielded the smallest value: $37 \mathrm{bpm}$, which is the result of low accuracy in command selection. In the latter mode, however, one user was able to enter commands accurately and showed the highest transfer rate of $287 \mathrm{bpm}$, with the command input time being 1 second and accuracy of 0.96 . The information transfer rate at the $m$-sequence period of 1 second was significantly different from the slow mode $(Z=2.7 ; p=0.019)$.

\section{The shape of evoked potentials and topographic distribution of evoked activity}

Figure 2 shows the shape of code-modulated evoked potentials averaged relative to the first bit of the sequence, restored for the zero-shift m-sequence.

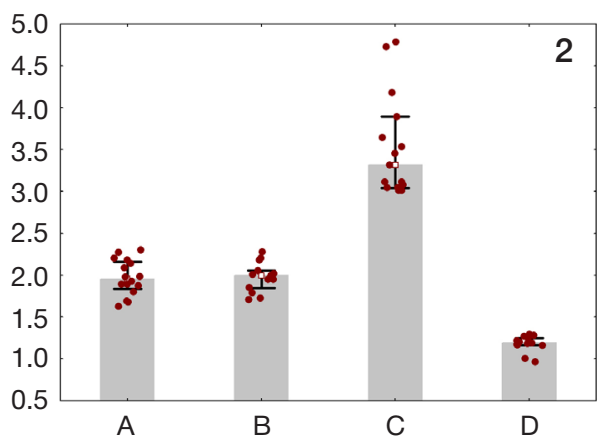


As a quantitative characteristic, we used the correlation between the averaged evoked potential and single potentials corresponding to single $\mathrm{m}$-sequences. Figure 3 shows the maps of maximum values of normalized cross-correlations between averaged evoked potentials and responses to single sequences.

According to the figure, the degree of similarity between evoked potentials reaches its maximum in occipital channels. All modes that allowed a high accuracy of command selection had the highest correlation degree at the $\mathrm{Oz}$ site. The maximum correlation was registered in 8 channels: P4, P6, PO3, POz, $\mathrm{PO} 4, \mathrm{O} 1, \mathrm{O} 2, \mathrm{Oz}$. The absolute values of the cross-correlation maxima do not differ significantly between the modes when compared in corresponding channels. In the fast mode, localization of evoked potentials was less pronounced, which is probably one of the reasons behind the poorest results shown by the participants.

\section{DISCUSSION}

Research of the CVEP-enabled $\mathrm{BCl}$ reveals a number of interesting patterns that play a role in the development of a high-quality medical neurocommunicator for a wide range of patients. First of all, it is the ratio between rate, accuracy of input and the overall information transfer rate peculiar to a specific modification of the interface. Obviously, from the user's viewpoint, the main property of a $\mathrm{BCl}$ is the information transfer rate. The data obtained indicate that this type of interface is capable of a transfer rate severalfold greater than that of the traditional $\mathrm{BCl}$ making use of $\mathrm{P} 300$, which makes the new interface a promising tool in the clinical practice. In the first three modes, the information transfer rate is within the limits usual for interfaces of this type [8, 14]. However, one participant managed to reach the rate of $287 \mathrm{bpm}$ in the fast mode, which proved impossible for the majority of other participants. This is an important fact; being unique for the sample, this result substantiates the development of a $\mathrm{BCl}$ that would allow fine tuning the parameters to individual characteristics of its user with the aim to find their optimal combination (stimulation rate in particular). Such an approach can help overcome the known problems associated with adaptation of results of laboratory research involving healthy participants to clinical practice [15]. Another problem it would solve is the so-called BCl-illiteracy, i.e. inability of patients to learn to operate a brain-computer interface [16]. There are different approaches to tackling these problems, including modification of the training stage [17] and
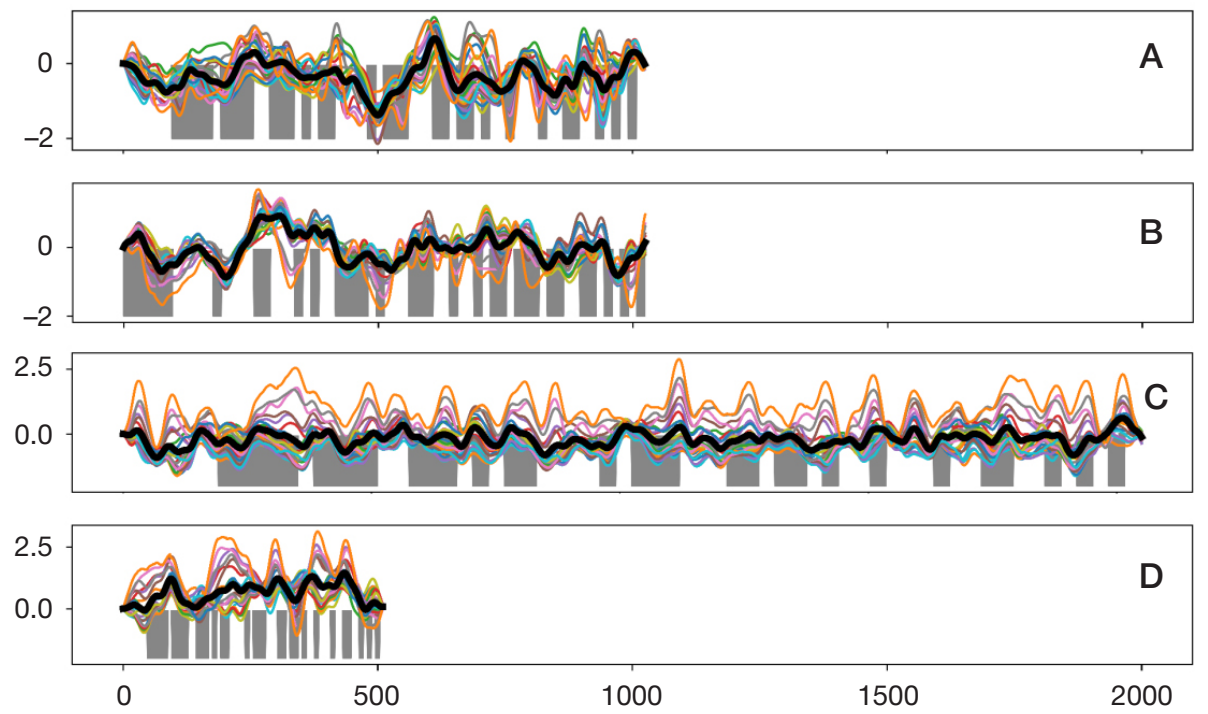

Fig. 2. Averaged evoked potentials registered during stimulation, all channels, shifted to zero shift relative to the basis m-sequence. The stimulus sequence is given in gray. One curve - one channel of the averaged EEG. The potential averaged between all channels is given in black

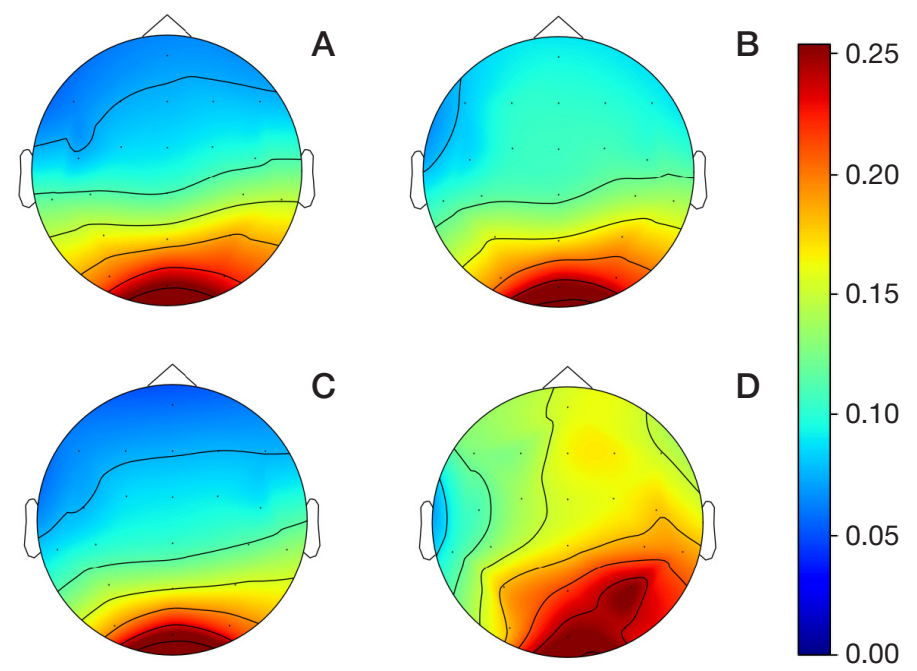

Fig. 3. Correlation function's maximum value maps, averaged for all participants, for averaged evoked potential of each channel (Fig. 2) and individual evoked potentials for single m-sequences. This indicator allows assessing the intensity of potential in all channels 
the individualization of interfaces. Fine tuning the m-sequence carrier frequency and its period could help find optimal values that maximize the information transfer rate for each specific user. In fact, this is a routine already practiced when tuning P300-based BCl [18]. Unfortunately, modern displays, even those with high refresh rates, do not allow sufficient flexibility in adjustment of the stimulus sequence period frequency for CVEP BCl. For example, in the context of this study we were unable to demonstrate a sequence with the period of 0.8 seconds, which suggests that designing a special device for such purpose would be feasible. Several such attempts have already been made (based on evoked potentials) [19], but the specific implementations presented offer a low information transfer rate due to the small number of stimuli.

\section{CONCLUSIONS}

The results of this study suggest that optimizing $\mathrm{BCl}$ operation for a user requires fine tuning the parameters depending on the individual characteristics of each such user. We have shown that inverting the coding stimulus sequence does not affect the accuracy of selection of commands by BCl users, which translates into equal applicability of both direct and inverted stimulation modes. At the same time, faster modes of $\mathrm{BCl}$ operation with the sequences twice shorter proved to be suboptimal for the majority of participants of the experiment. The significant individual differences in accuracy and information transfer rate revealed by this study suggest that it is possible to optimize $\mathrm{BCl}$ through its fine-tuning to the specifics of the given patient.

\section{References}

1. Kaplan AY. Neurophysiological foundations and practical realizations of the brain-machine interfaces in the technology in neurological rehabilitation. Hum Physiol. 2016 Jan 23; 42 (1): 103-10.

2. Wolpaw JR, Birbaumer N, McFarland DJ, Pfurtscheller G, Vaughan TM. Brain-computer interfaces for communication and control. Clin Neurophysiol [Internet]. 2002 Jun; 113 (6): 767-91. Available from: http://www.ncbi.nlm.nih.gov/pubmed/12048038.

3. Jeunet C, Lotte F, Batail J-M, Philip P, Micoulaud Franchi J-A. Using Recent $\mathrm{BCl}$ Literature to Deepen our Understanding of Clinical Neurofeedback: A Short Review. Neuroscience [Internet]. 2018 May 15 [cited 2018 Jul 24]; (378): 225-33. Available from: https://mww.sciencedirect.com/science/article/pii/S0306452218302045.

4. Akram F, Han H-S, Kim T-S. A P300-based brain computer interface system for words typing. Comput Biol Med [Internet]. 2014 Feb [cited 2014 Jun 1]; (45): 118-25. Available from: http:// www.ncbi.nlm.nih.gov/pubmed/24480171.

5. Yeom SK, Fazli S, Ller KRM, Lee SW. An efficient ERP-based brain-computer interface using random set presentation and face familiarity. PLoS One. 2014; 9 (11): 1-13.

6. Guger C, Allison BZ, Edlinger G. Emerging BCl Opportunities from a Market Perspective. In Springer, Dordrecht; 2014 [cited 2018 Jul 16]: 85-98. Available from: http://link.springer.com/10.1007/97894-017-8996-7_7.

7. McCane LM, Heckman SM, McFarland DJ, Townsend G, Mak JN Sellers EW, et al. P300-based brain-computer interface $(\mathrm{BCl})$ event-related potentials (ERPs): People with amyotrophic latera sclerosis (ALS) vs. age-matched controls. Clin Neurophysiol [Internet]. 2015 Nov 1 [cited 2018 Jul 16]; 126 (11): 2124-31. Available from: https://www.sciencedirect.com/science/article/ pii/S138824571500067X.

8. Bin G, Gao X, Wang Y, Li Y, Hong B, Gao S. A high-speed BCl based on code modulation VEP. J Neural Eng. 2011; 8 (2): 025015.

9. Kapeller C, Kamada K, Ogawa H, Prueckl R, Scharinger J, Guger C. An electrocorticographic $\mathrm{BCl}$ using code-based VEP for control in video applications: a single-subject study. Front Syst Neurosci [Internet]. 2014 Aug 7 [cited 2018 Jul 17]; (8): 139. Available from: http://journal.frontiersin.org/article/10.3389/fnsys.2014.00139/ abstract.

10. Spüler M, Rosenstiel W, Bogdan M. Online Adaptation of a c-VEP Brain-Computer Interface $(\mathrm{BCl})$ Based on Error-Related Potentials and Unsupervised Learning. Baumert M, editor. PLoS One
[Internet]. 2012 Dec 7 [cited 2018 Jul 17]; 7 (12): e51077. Available from: http://dx.plos.org/10.1371/journal.pone.0051077.

11. Nezamfar H, Salehi SSM, Erdogmus D. Stimuli with opponent colors and higher bit rate enable higher accuracy for C-VEP BCl. In: 2015 IEEE Signal Processing in Medicine and Biology Symposium (SPMB) [Internet]. IEEE; 2015 [cited 2018 Jul 17]: 1-6. Available from: http://ieeexplore.ieee.org/document/7405476/.

12. Jones E, Oliphant T, Peterson P. \{SciPy\}: Open source scientific tools for $\{$ Python\}. 2001.

13. Yuan P, Gao X, Allison B, Wang Y, Bin G, Gao S. A study of the existing problems of estimating the information transfer rate in online brain-computer interfaces. J Neural Eng [Internet]. 2013 Apr 1 [cited 2018 Jul 16]; 10 (2): 026014. Available from: http:// stacks.iop.org/1741-2552/10/i=2/a=026014?key=crossref.0e89 a1992040af23792558b5b8301c22.

14. Wei Q, Gong H, Lu Z. Grouping modulation with different codes for improving performance in CVEP-based brain-computer interfaces. Electron Lett. 2017 Jan 10; 53 (4): 214-6.

15. Kleih SC, Kaufmann T, Zickler C, Halder S, Leotta F, Cincotti F, et al. Out of the frying pan into the fire-the P300-based BCl faces real-world challenges. Prog Brain Res [Internet]. 2011 Jan 1 [cited 2018 Jul 16]; (194): 27-46. Available from: https://www. sciencedirect.com/science/article/pii/B9780444538154000194.

16. Spezialetti M, Cinque L, Tavares JMRS, Placidi G. Towards EEGbased $\mathrm{BCl}$ driven by emotions for addressing BCl-Illiteracy: a meta-analytic review. Behav Inf Technol [Internet]. 2018 Aug 3 [cited 2018 Jul 16]; 37 (8): 855-71. Available from: https://www. tandfonline.com/doi/full/10.1080/0144929X.2018.1485745.

17. Jeunet C, Cellard A, Subramanian S, Hachet M, N'Kaoua B, Lotte F. How Well Can We Learn With Standard BCl Training Approaches? A Pilot Study. 2014 [cited 2018 Jul 16]; Available from: https://hal.archives-ouvertes.fr/hal-01052692/.

18. Carabalona R. The Role of the Interplay between Stimulus Type and Timing in Explaining BCl-Illiteracy for Visual P300-Based Brain-Computer Interfaces. Front Neurosci [Internet]. 2017 Jun 30 [cited $2018 \mathrm{Jul}$ 16]; (11): 363. Available from: http://journal. frontiersin.org/article/10.3389/fnins.2017.00363/full.

19. Aminaka D, Rutkowski TM. A Sixteen-Command and $40 \mathrm{~Hz}$ Carrier Frequency Code-Modulated Visual Evoked Potential BCl. In Springer, Cham; 2017 [cited 2018 Jul 16]: 97-104. Available from: http://link.springer.com/10.1007/978-3-319-64373-1_10.

\section{Литература}

1. Kaplan AY. Neurophysiological foundations and practical realizations of the brain-machine interfaces in the technology in neurological rehabilitation. Hum Physiol. 2016 Jan 23; 42 (1): 103-10.

2. Wolpaw JR, Birbaumer N, McFarland DJ, Pfurtscheller G,
Vaughan TM. Brain-computer interfaces for communication and control. Clin Neurophysiol [Internet]. 2002 Jun; 113 (6): 767-91. Available from: http://www.ncbi.nlm.nih.gov/pubmed/12048038. 3. Jeunet C, Lotte F, Batail J-M, Philip P, Micoulaud Franchi J-A. 
Using Recent $\mathrm{BCl}$ Literature to Deepen our Understanding of Clinical Neurofeedback: A Short Review. Neuroscience [Internet]. 2018 May 15 [cited 2018 Jul 24]; (378): 225-33. Available from: https://www.sciencedirect.com/science/article/pii/S0306452218302045.

4. Akram F, Han H-S, Kim T-S. A P300-based brain computer interface system for words typing. Comput Biol Med [Internet]. 2014 Feb [cited 2014 Jun 1]; (45): 118-25. Available from: http:// www.ncbi.nlm.nih.gov/pubmed/24480171.

5. Yeom SK, Fazli S, Ller KRM, Lee SW. An efficient ERP-based brain-computer interface using random set presentation and face familiarity. PLoS One. 2014; 9 (11): 1-13.

6. Guger C, Allison BZ, Edlinger G. Emerging BCI Opportunities from a Market Perspective. In Springer, Dordrecht; 2014 [cited 2018 Ju 16]: 85-98. Available from: http://link.springer.com/10.1007/97894-017-8996-7 7

7. McCane LM, Heckman SM, McFarland DJ, Townsend G, Mak JN Sellers EW, et al. P300-based brain-computer interface (BCl) event-related potentials (ERPs): People with amyotrophic lateral sclerosis (ALS) vs. age-matched controls. Clin Neurophysiol [Internet]. 2015 Nov 1 [cited 2018 Jul 16]; 126 (11): 2124-31. Available from: https://www.sciencedirect.com/science/article/ pii/S138824571500067X.

8. Bin G, Gao X, Wang Y, Li Y, Hong B, Gao S. A high-speed BCl based on code modulation VEP. J Neural Eng. 2011; 8 (2): 025015

9. Kapeller C, Kamada K, Ogawa H, Prueckl R, Scharinger J, Guger C. An electrocorticographic $\mathrm{BCl}$ using code-based VEP for control in video applications: a single-subject study. Front Syst Neurosci [Internet]. 2014 Aug 7 [cited 2018 Jul 17]; (8): 139. Available from: http://journal.frontiersin.org/article/10.3389/fnsys.2014.00139/ abstract.

10. Spüler M, Rosenstiel W, Bogdan M. Online Adaptation of a c-VEP Brain-Computer Interface $(\mathrm{BCl})$ Based on Error-Related Potentials and Unsupervised Learning. Baumert M, editor. PLoS One [Internet]. 2012 Dec 7 [cited 2018 Jul 17]; 7 (12): e51077. Available from: http://dx.plos.org/10.1371/journal.pone.0051077.

11. Nezamfar H, Salehi SSM, Erdogmus D. Stimuli with opponent colors and higher bit rate enable higher accuracy for C-VEP BCI. In:
2015 IEEE Signal Processing in Medicine and Biology Symposium (SPMB) [Internet]. IEEE; 2015 [cited 2018 Jul 17]: 1-6. Available from: http://ieeexplore.ieee.org/document/7405476/.

12. Jones E, Oliphant T, Peterson P. \{SciPy\}: Open source scientific tools for \{Python\}. 2001.

13. Yuan $P$, Gao X, Allison B, Wang $Y$, Bin G, Gao S. A study of the existing problems of estimating the information transfer rate in online brain-computer interfaces. J Neural Eng [Internet]. 2013 Apr 1 [cited 2018 Jul 16]; 10 (2): 026014 . Available from: http:// stacks.iop.org/1741-2552/10/i=2/a=026014?key=crossref.0e89 a1992040af23792558b5b8301c22.

14. Wei Q, Gong H, Lu Z. Grouping modulation with different codes for improving performance in CVEP-based brain-computer interfaces. Electron Lett. 2017 Jan 10; 53 (4): 214-6.

15. Kleih SC, Kaufmann T, Zickler C, Halder S, Leotta F, Cincotti F, et al. Out of the frying pan into the fire-the P300-based BCl faces real-world challenges. Prog Brain Res [Internet]. 2011 Jan 1 [cited 2018 Jul 16]; (194): 27-46. Available from: https://www. sciencedirect.com/science/article/pii/B9780444538154000194.

16. Spezialetti M, Cinque L, Tavares JMRS, Placidi G. Towards EEGbased $\mathrm{BCl}$ driven by emotions for addressing $\mathrm{BCl}$-Illiteracy: a meta-analytic review. Behav Inf Technol [Internet]. 2018 Aug 3 [cited 2018 Jul 16]; 37 (8): 855-71. Available from: https://www. tandfonline.com/doi/full/10.1080/0144929X.2018.1485745.

17. Jeunet C, Cellard A, Subramanian S, Hachet M, N'Kaoua B, Lotte F. How Well Can We Learn With Standard BCl Training Approaches? A Pilot Study. 2014 [cited 2018 Jul 16]; Available from: https://hal.archives-ouvertes.fr/hal-01052692/.

18. Carabalona R. The Role of the Interplay between Stimulus Type and Timing in Explaining BCl-Illiteracy for Visual P300-Based Brain-Computer Interfaces. Front Neurosci [Internet]. 2017 Jun 30 [cited 2018 Jul 16]; (11): 363. Available from: http://journal. frontiersin.org/article/10.3389/fnins.2017.00363/full.

19. Aminaka D, Rutkowski TM. A Sixteen-Command and $40 \mathrm{~Hz}$ Carrier Frequency Code-Modulated Visual Evoked Potential BCl. In Springer, Cham; 2017 [cited 2018 Jul 16]: 97-104. Available from: http://link.springer.com/10.1007/978-3-319-64373-1_10. 